\title{
INSTRUMENTS-IMAGES IN MUSICAL SCIENCE AND PRACTICE
}

\section{Chernoivanenko A. D.}

\section{INTRODUCTION}

Since the second half of the XX century, the semiological potentials of science (and the development of semiotics as a special science), which are gaining strength, began to actively penetrate into musical aesthetics and musicology. This process was facilitated in many respects by musical avant-garde movements, the figurative and technological parameters of which stimulated debates about the ability of music to express specific meanings using concrete (primarily instrumental) means. A certain confrontation unfolded between the supporters of music interpretation as an asemantic reality and as a system of signs. And although, on the whole, more supporters found a statement about music as a means of specific artistic communication, the mechanisms and nature of musical significance, symbolism, sign remain today promising objects of scientific research. The point here is not only the need for a certain sign system in a "pure" musical and instrumental "message", communication, where there is no verbal text that largely determines or contributes to the formation of a holistic meaning, as well as purely musical intonations in terms of instrumental accompaniment to singing. In purely instrumental creativity, the mechanisms of associative-sound memory are activated, preserving certain semiotic signs of the instrument itself in its materialized organological (timbre, type of instrument, methods and techniques of the play), as well as situational and substantive (ritual, leisure, work processes, etc.) and genre and style expressions.

With time out of mind, from birth to death, in various layers of life from work and leisure to spiritual and aesthetic, a person has been accompanied by music, song, and dance. Musical instruments are an integral part of all these events, rituals and reflections: from primitive to the most complex and most sophisticated in acoustic and even engineering terms, from hand-made from "improvised means" to masterful works of art, such as, for example, the Guarneri and Stradivarius violins, which in the hands of the master and performer are capable to express the finest facets of complex mental and sensory 
processes. It is clear that a musical instrument is unique (and for a performer it is often spiritually personified, miraculously mythological), a co-creator in broadcasting musical ideas, and not an independent, self-sufficient expresser of them. However, in a complex system ("semiosphere") of instrumental creativity, this instrument in the process of performing an act is spiritualized in a certain way and possesses characteristics not only of a carrier (sound, situational and symbolic, substantial and style) image, but also an initiator of linguistic and figurative structures capable of directing the development of musical thought of its creator - man.

Various types and modifications of musical instruments, constants and changes in their symbolic meaning fully reflect the movement of the cultural and historical process as a whole, the evolution of the picture of the world and the collision of man and the universe in its wholeness. The symbolism of musical instruments has played an important role for thousands of years in life, thinking and various types of creativity in connection with the place that music occupies in the spiritual life and culture of mankind. Therefore, elucidation of the basic principles of such symbolism is an actual scientific direction in musicology (and wider) research. And it is here that structural semiotic approach, developed by Y. M. Lotman, is effective as one of the important ways to comprehend complex objects, such as an art work, the cultural era, musical and instrumental culture and musical instruments themselves. The structural method, according to Y. Lotman, ensures the logic of the study, the validity of the conclusions and the ability to show the integrity of the object.

\section{A musical instrument in the light of the structural and semiotic concept}

The study of musical and instrumental culture, from its ancient and folklore samples to works of high professional composer music of recent eras and modern times, is in the field of scientific principles for the study of culture as a whole and the mechanisms that generate it, formulated by Y. Lotman. This refers to its understanding of two-dimensional and twohemisphere consciousness according to the scheme of structural binary oppositions (logical - mythological, discrete - continuous, material ideational). According to the theory of Lotman's structural and semiotic concept, art works of past (including very distant) eras of culture «continue to actively participate in its development as living factors». In culture, not only the immediate chronological period "works", but "the 
entire thickness of the culture texts, everything that is contained in its memory, is directly or indirectly included in its synchrony" 1 .

In this regard, a musical instrument, even if it has undergone significant modernization, retains the entire "plume" of its historical properties - functionally situational, genre, style, and semantic qualities, somehow introducing them into new linguistic and style data. The instrument as a "living factor" for the further development of its own "semiosphere" translates accumulated signs-symbols, and the composer and performer superimpose on them new formed ones, in accordance with the epoch-style, individual-style settings, and general heuristic positions of creativity.

Thus, within each musical and instrumental culture (as well as in musical instrumentalism as a whole), semiotic diversity is constantly increasing, while maintaining the key stable, centuries-old symbolic characteristics of instrumental materiality - the timbre, the ways of «communication» of the performer with the instrument, that is the methods of sound production and sound science, etc. (for example, the emotional sensuality of the bow, relative neutrality of the pinch, significant neutrality of the piano).

Each of these, having the value of the sign organization nodes, is able to show a tendency to become a kind of "cultural personality" (Y. Lotman) - a "closed immanent world with its own internal structural and semiotic organization, its own memory, individual behavior, intellectual abilities and self-development mechanism» ${ }^{2}$. As a result, the musical and instrumental culture as a whole, as a system, as a whole organism, is a combination of such "quasi-personal" semiotic formations and the communication system between them in the system "composer instrument - performer - listener» in different positions, between instrumental and vocal creativity, between various types of arts, in culture, within and between eras, national conditions, etc.

One of the principles of the structure organization is binary relations. But the result of the system description is often rigid structural poles, and a wide strip of neutral elements having a dual relationship to them is simply not captured. This removes the internal incomplete ordering of

1 Зайнетдинова Р.А. Становление проблемного поля концепции семиосферы Ю.М. Лотмана: историко-философский анализ: автореф. дисс. ... канд. филос. наук: 09.00.03. Екатеринбург, 2011. С. 21.

2 Зайнетдинова Р.А. Становление проблемного поля концепции семиосферы Ю.М. Лотмана: историко-философский анализ: автореф. дисс. ... канд. филос. наук: 09.00.03. Екатеринбург, 2011. С. 21. 
the system, which gives it flexibility and increases the degree of behavior unpredictability. Ambivalence (duality, ambiguity) as a certain cultural and semiotic phenomenon was first described in the works of M. M. Bakhtin. The growth of internal ambivalence corresponds to the moment the system transitions to a dynamic state. Also, one of the mechanisms of semiotic evolution is the swing between the dynamic state of indescribability and the statics of self-descriptions.

In music, there is a type of signs, the so-called «symbols of receptive expectation, thanks to which the listener prepares himself in advance for what is to be heard» ${ }^{3}$. The action of such symbols extends not only to the spheres of musical intonation (in the broad sense), image, thematism, harmony, but also to the image of the instruments themselves. For example, brass instruments are expected to be embodied in heroics, fanfare invocations, hunting or military personifications and generalizations, and from the end of the XX century - jazz-pop manifestations. Bowed stringed instruments - maximum imitation of the human voice or concert-virtuoso imagery. The organ - sublime spiritual incarnations.

The accordion or bayan - rather popular-democratic, pop or folk music. A neutral in timbre piano - sonata-symphonic concepts, chamberrefined images (associated with professional composing), jazz rhythms, etc.

In this sense, the concept "sound image of an instrument", derived already in the XX century, is important. L. Gakkel introduced the concept of a "sound image of an instrument" into musicology in the book "Piano Music of the XX Century", obviously, based on the term of A. Copland "sonorous image" from his work "Music and imagination". Copland establishes a close relationship between the evolution of the instrument, as a constructiveacoustic phenomenon, and composer creativity. Gakkel, using the term a sound image relative to a specific instrument - the piano, gives the original concept of Copland a slightly different semantic meaning, referring to the "sound material of music" and the impression, the impact of music on the

3 Лазутина Т.В. Процесс символизации в музыке: дис. ... канд. филос наук: 09.00.01. Тюмень, 2003. С. 123.

${ }^{4}$ Гаккель Л. Фортепианная музыка ХХ века: Очерки. 2-е изд., доп. Л.: Сов. композитор, 1990. 288 с.

5 Copland A. Music and imagination. Cambridge: Harvard University Press, 1952. Second printing. 
listener". A. Malinkovskaya introduces the concept of "sound complex" (sound image) of a piano, which is closely interconnected with a wide range of means of piano expressiveness ${ }^{7}$. The scientific apparatus of the dissertation work by T. Budanova is based on Gakkel's terminology. The "sound image of an instrument" is considered in the triad "organics (instrument construction) - intonational meaning, realized through a complex of means of artistic expression - the listener's perception" Through comprehension of this triad, the author comes to the definition of the sound image in two aspects - wide and narrow. The first is "the sound material of music, reproducing in intonation practice the whole variety of manifestations of functional polyvalence. The second is the concrete facet of this multivalence ("bayan image", "harpsichord image", "piano", "jazz", "impressionistic", "romantic", "constructivist", "elitist", etc.). S. Ivanova proposes the concept of "sound image of an instrument", three interrelated and interdependent factors becoming essential for its evolution: performing traditions, the composer's musical text and the results of improving instrument designs in order to identify new expressive techniques and expand technical capabilities ${ }^{9}$. We would add here the cultural and historical context of the instrument appearance and evolution, the symbolic field that was formed with its participation in the spiritual, ritual, leisure and everyday, literary and poetic, pictorial and philosophical contexts. A. Timoshenko's dissertation work is connected with these problems, exploring the notions of sound, the concept of the instrument and composition of American composers. It introduces the notion "artistic and acoustic type of instrument" related to the mentioned above, which means "the musical and acoustic qualities of the instrument accepted by one tradition or another and developed executive techniques of playing it, as well as an idea of the boundaries of this instrument capabilities"10.

6 Гаккель Л. Фортепианная музыка XX века: Очерки. 2-е изд., доп. Л.: Сов. композитор, 1990. С. 6

7 Малинковская А.В. Класс основного музыкального инструмента. Искусство фортепианного интонирования. М.: Владивосток, 2002. 381 с., нот.

${ }^{8}$ Буданова Т. Музыка для баяна композиторов Сибири и Дальнего Востока: автореф. дисс... канд. искусств.: 17.00.02. Владивосток, 2009. С. 27.

9 Иванова С. Эволюция звукового образа балалайки: автореф. дисс... канд. искусств.: 17.00.02. Магнитогорск, 2009. С. 9.

10 Тимошенко А. Американский музыкальный экспериментализм первой половины XX века: представление о звуке, концепция инструмента, композиции (Г. Коуэлл, Дж. Кейдж, Л. Хэррисон): дисс. ... канд. искусств.: 17.00.02. СПб., 2004. С. 16. 
Among the phrases aimed at determining the essence of the instrument interpretation, we also meet the concept of "image of the instrument" (in an acoustic, not in a poetic, mythological or pictorial sense) without a qualifying adjective "sounding" or "sound"11. According to the author, the characteristics of the instrumental style «in relation to the signs of the composer's style ... create the image of a musical instrument». The author notes that the formation of instrumentalism is significantly influenced by the structure of the instrument and the "specificity of intonation being". The signs of the composer's style are manifested in the fact that the artist selects and adapts the technical, acoustic and expressive capabilities of the instrument to his own plan, for example, methods of sound production, manner of performance, genre semantics, as well as "intonation dictionary" (B. Asafev).

N. Ryabukha analyzes the concept of a "sound image" as a cultural concept, as a historical and cultural image of the era, which reflects the sound and musical consciousness of society: "A sound image as an established (but not yet sufficiently studied) category of musical creativity and thinking is an informational art "code" of a work in which the image of a person and his historical time in the space of sound being is contained in a convoluted form» ${ }^{12}$.

It should be emphasized that in all forms of musical creativity there is always a figurative beginning, since any art form involves a figurative reincarnation of objective reality. However, the instrument itself, accumulating the experience of organological improvement, the performing skills of playing it and the composer's repertoire with the corresponding ideological and figurative genre and style baggage, is able to act as an image, more precisely as a sign-image, which is characterized by the binary nature of instrumental, material and ideational (spiritual and philosophical, cultural, historical, social) parameters in their organological, performing, composer aspects. Their combination, interconnections and mutual influences give grounds for creating a kind of "cultural personality" - an instrument of the era, nation, style, genre, individual quality with specific and universal characteristics.

11 Башарова И. Образ флейты в сонатине Губайдуллиной. Вестник Башкирского Университета. Уфа, 2008. №3. С. 595-598.

12 Рябуха Н. Звуковий образ як феномен культури: досвід міждисциплінарного синтезу. Культура і сучасність. К., 2014. Вип. 2. С. 116. 
Complex iconic formations in music direct the attention of the listener, composer and performer to the subject of attention. The dominant sign (symbol) causes a certain reaction, which is correlated with other sign (symbolic) couplings that correct the "boundaries of the general expectation" based on the immediate task ${ }^{13}$.

\section{Musical instruments-images in literary and poetic creativity}

Musical images, and above all, musical instruments, due to their symbolism accumulated over centuries, receive various forms of aesthetic embodiment in culture, in various types of art. Here they become images of the music itself, capable of (with or without words, in pure instrumental quality) embodying ideas that are a little accessible or inaccessible to translation into a verbal language (due to the specificity of the musical language ${ }^{14}$ ). According to L. Herver, the images of musical instruments largely determine the ideological and figurative field in mythology and literature ${ }^{15}$. It was in mythology that the foundations of the symbolic "reading" of various instruments in philosophy, painting, literature, music itself and human life were formed. Herver argues that the images of musical instruments are an important link of all time «just like real instruments, which have preserved the principles of sound production and a number of names since the beginning of time» ${ }^{16}$. That means, the instrument acts as a mediator, a special form of communication and the existence of mankind in the cultural and temporal vertical in a semiological context.

The brightest examples of such musical and instrumental imagery are presented not only in the mythological symbolism of all peoples, without exception, where the musical instrument enters into a relationship of transformation and identity with all elements of the mythological world and with this world itself; an important role is played here by the origin and belonging of musical instruments, often received as gifts from gods or cultural heroes, or made by them. Already in ancient mythology various types of musical instruments are reflected with the corresponding

${ }^{13}$ Семиотика: Антология / сост. Ю.С. Степанов. Изд. 2-е, испр. и доп. М.: Академический проспект; Екатеринбург: Деловая книга, 2001. С. 73.

14 Chernoivanenko A. Musical and instrumental foundations of modern composition techniques. National academy of managerial staff of culture and arts Herald. 2'2019. S. 444-448.

15 Гервер Л. Музыка и музыкальная мифология в творчестве русских поэтов (первые десятилетия XX века). М.: Индрик, 2001. С. 67.

16 Там же. 
division of spheres of influence, which is «marked by stringed - wind percussion instruments (sometimes stringed - wind + percussion), which are owned by: men and women, celestials and people, etc." ${ }^{17}$ A. Losev points out that among the Greeks not all instruments were considered suitable for musical education (for example, the flute was excluded).

In the «Revelation of St. John the Evangelist,» concluding the Bible, the birth of a new world begins after the Last Judgment and the end of the world. When depicting the Apocalypse, the symbolic meaning is embodied in the images of trumpets: "And I saw seven Angels who stood before God; and they were given seven trumpets» ${ }^{18}$. The trumpet has long been used for delivering certain signals on the hunt, in the military affairs. In this regard, it is logical that the alternate sounding of seven trumpets in the Apocalypse means the beginning of the end of the world. Interesting is the fact that in S. Esenin's "Sorokoust", the death of the world (the village) announces the "death horn", and not the trumpet of the apocalypse angel, but from the shepherd's horn, predicting the death of the village world"19. In the musical work itself, the horn is also a symbol and image: the golden passage of the horn (Haydn, Mendelssohn, Tchaikovsky), the horn of Oberon in Weber's opera, etc.

In the Christian picture of the world of the Middle Ages, there was a divine and harmonious music of the heavenly spheres and the infernal music of the Sabbath of witches. Fantastic musical instruments with figures of people crucified on them appear in the paintings of I. Bosch. Angels are depicted with harps or flutes. For a romantic person, the metaphor of a "broken heart" often appeared in associative connection with torn strings and a broken musical instrument. "Evolution, moving in the direction of more and more "animation" and personification of the instrument, and, first of all, the replacement of wind instruments with stringed ones, reaches its goal here - in the work of romantics, it becomes a double of the hero, his second «II», sensitively reacting to all the throwing and suffering of the romantic soul"20. It is necessary to note that in European culture, starting from the Renaissance, the violin is a symbol of the female voice, soul.

${ }^{17}$ Гервер Л. Музыка и музыкальная мифология в творчестве русских поэтов (первые десятилетия XX века). М.: Индрик, 2001. С. 67.

${ }^{18}$ Откровение. 8:2. Новый завет.

19 Воронова О.Е. Сергей Есенин и русская духовная культура. Рязань: Узорочье, 2002. С. 396.

20 Карабегова Е. Символика музыкальных инструментов в немецкой литературе XIX - XX веков и «Контрабас» Патрика Зюскинда. 
The variety of musical instruments, the «world orchestra» should also be understood as a symbol of the spiritual order. Rightly pointing out that "musical instruments alone cannot reproduce praise" ${ }^{21}$, P. Masters notes the ability of the sound characteristics of various instruments to describe «various feelings inherent in true worship».

A whole system of musical and instrumental imagery was built by symbolist poets and acmeists in the XX century. It is interesting that V. Khlebnikov in his essay "Our Foundation" proves (based on the methods of physics) a new temporary law that he "discovered": the repeatability of historical phenomena allows us to divide the history of mankind into periods and thus predict the future. According to his theory, the poet sought to recreate the original unity, overcoming the fragmentation of time, which disperses all that exists. For new people who are immortal and who have mastered the secrets of time, that is, "aveniristes", carriers of "higher intelligence", according to Khlebnikov, a new adequate system is needed. There semantically significant sounds play the main role, each of which "hides a certain image and is a name» and voices the physical laws of body motion. ${ }^{22}$ In such sound semantics, the leading role is played by image instruments. For Khlebnikov, these are images of the "trumpet of the world", "strings" (here the strings and winds are universalized, losing the acuteness of the ancient Greek confrontation), "harp of time", "balalaika of time" (national component), and the lyrical hero feels himself simultaneously in the present, in the past and eternity. The indicated by Khlebnikov original images of musical instruments are beyond the action of life and death, their destiny is eternity. Thus, image instruments illustrate the structure of the semantic field of Khlebnikov's utopian theory of time and the desire to grasp the internal energy, the conventions of life and poetic language ${ }^{23}$.

Very often it is the images of musical instruments in literature and poetry that function to convey the emotional state of the lyrical hero (for example, a bell, piano, violin - by O. Mandelstam; guitar, violin, harmonica - by S. Yesenin; harp, violin, bell, orchestra - by Annensky, etc.). It is noteworthy that Mandelstam's universal lyrical hero (European, heir to the values of the entire "Judeo-Christian-Hellenic culture" rather than the culture of his country ${ }^{24}$ ) "chooses" mainly

${ }^{21}$ Мастерс П. Богослужение: библейское и современное.

22 Давыдова А.В. Музыкальные образы в русской лирике начала ХХ века: автореф. дисс. ... канд. филол. наук. Архангельск, 2006. С. 12.

23 Давыдова, 2006. С. 16.

24 Давыдова, 2006. С. 17. 
academic instruments, gravitating in their status to universalism, the European center, demonstrating the synchronism of existence of temporary, genre, national principles, sealed with a «moral personal memory" 25 . S. Yesenin, by contrast, through a musical instrument transmits the national principle (harmonica, guitar).

Considering the mythology associated with musical instruments, L. Herver states: "The more musical a work of literature is, the more mythological it is. And in order to understand how his musical form works, sometimes it is necessary first of all to carry out a mythological analysis" 26 . In Yesenin's "Sorokoust", for example, literary scholars find the leading principle of musical drama (according to B. Asafiev) juxtaposition and interaction of contrasting imaginative spheres: biblical mythology embodied in the image of the "perishing horns" and the myth of the last village poet associated with the image of "crying" harmonica. The antithesis of the sound of two musical instruments is: the "death horn" and the "voiced talianka" correlates with the tragic confrontation of these images, which confirms the validity of the statement by A. Davydova: "The musical images reflected the catastrophic consciousness of a person on the verge of the XIX - XX centuries related to the feeling of inevitable fatal changes" ${ }^{27}$. This musical form is transmitted through the images of musical instruments; it becomes a characteristic feature of twentieth-century poetry.

However, the binary nature of the figurative spheres can be embodied in the monotheme of musical instruments. So, the image of the guitar appears with many sides, transforms in its personification throughout the entire career of Yesenin (it is either a tavern, a "cursed", or a noble compared to a harmonica). An anthropologically personified image of the string as a naked nerve of a musical instrument and a lyrical hero is interesting. Therefore, this image often has a confessional character; it is associated with the desire of the lyrical hero to express the most secret.

Thus, musical images (primarily instruments), being the embodiment of the idea of artistic synthesis and realizing the principles of musicality, occupy an important place in the poetry of the XX century. Images of musical instruments are used mainly to characterize the lyrical hero; a figurative description of the elements of the external world, the sound

25 Давыдова, 2006. С. 16.

${ }^{26}$ Гервер Л. Музыка и музыкальная мифология в творчестве русских поэтов (первые десятилетия XX века). М.: Индрик, 2001. С. 163.

27 Давыдова А.В. Музыкальные образы в русской лирике начала XX века: автореф. дисс. ... канд. филол. наук: 10.01.01. Архангельск, 2006. С. 14. 
characteristics of a particular phenomenon - by likening one element to another according to the similarity of certain signs. This helps to achieve a special artistic effect. Even if musical images are not central, fundamental to a poetic picture of the world, they perform a number of functions, namely, they combine a number of artistic images of music, through the implementation of which the poet learns the world. Musical images also reflect the psychological state of the lyrical hero, transmit intimate experiences. And even the absence of any musicality can be interpreted as bad times coming. Since the lyrical, personal principle plays an important role in poetry, musical imagery helps to realize this semantic field.

Each instrument, as a sound symbol of the era, of national culture, in which it particularly clearly showed its capabilities in reflecting cultural and musical paradigms or even contributed to the creation of these paradigms, has historical preconditions for interpreting sonority, which determine its ability to reflect the concept of intonated attitude.

\section{Image of the instrument in performing and composer's work of the XX - XXI centuries (on the example of partita by S. Gubaidullina «Seven Words»)}

Since ancient times, musical instruments were endowed not only with personalized, anthropological features, but also acquired special symbolism, semantic qualities assigned to this type of instrumentation. Therefore, musical and instrumental art was deeply revered already in antiquity. So, in the Sumerian-Babylonian kingdom, sacrifices were performed in honor of musical instruments. According to the ideas of the Sumerians, the gods were not only music lovers, but also musicians. And in the state hierarchy of Sumer, the musicians stood directly behind the gods and kings. Historical sources allow us to talk about a rich, diverse and relatively perfect musical instrumentation by the beginning of the III millennium BC. Along with images of musical instruments, scientists also found the remains of the instruments themselves: a variety of percussion instruments (mainly drums and sistrums); among the winds an archaic longitudinal flute, close to the ancient Egyptian, reed - like the oboe; among strings there are (as in Ancient Egypt) harp-shaped lyres, harps, lutes. In the ensembles of Sumer-Babylonia, percussion instruments are combined with strings and winds. The kalu-priests (singers) accompanied their "performances" with playing musical instruments (the applicant for the title of priest should have possessed this, together with other skills). The ritual of the Kalu mass is described in Uruk texts with the smallest details. Methods of playing musical 
instruments are also indicated, in particular those relating to lilissu (obviously corresponding to the tympanum). It even describes a method of making it, painted with sacredness: it all starts with the sacrifice of a bull that must give its skin for lilissu. In general, the musical instruments of the Sumerians were of particular cult significance. So, for example, harp, trumpet, drum were also used as a means of scaring away evil spirits. They received magical power as a result of the priest's manipulations. Rituals were performed with singing hymns and prayers of thanks accompanied by a harp, flute and drum. The trumpet and drum depicted the «voice» of the deity. In the ancient cult of the dead, a funeral procession went to the burial place with the music of trumpets, drums and the choir of church singers. In Sumer-Akkadian mythology, Gilgamesh made a sacred drum.

The ancient Greek opposition of strings and winds symbolized the Apollonian and Dionysian principles, which received a philosophical interpretation from Nietzsche. They manifest two poles of a diverse human culture. For Nietzsche, Apollo is the embodiment of the spirit of Hellas, the Greek classics, a bright, rational beginning, in contrast to the Dionysian currents - dark, ecstatic, passionate, chaotic, orgiastic and irrational. Nietzsche saw the ideal in the balance of the Apollonian and Dionysian. Their synthesis consists in struggle and unity. The highest synthesis of plastic art of images and non-plastic art of music is enclosed in ancient tragedy. From Losev's point of view, Nietzsche's both beginnings bear the stamp of a new European outlook, characteristic of "romanticism" with its endless aspiration and formation of an idea ${ }^{28}$.

It is interesting that the symbolism of musical instruments is used in the musical concepts themselves, in musical works. So, in S. Gubaidullina's partita "The Seven Words of Christ" for the bayan, cello and chamber orchestra, pierced by symbolism by virtue of the concept itself, the bayan stands on behalf of God the father, the cello - God the son, and Music itself - the Holy Spirit.

The idea of the work is connected with the high spiritual secret of mankind in the events of biblical history: the cross sufferings of the Son of God, His resurrection and the salvation of the world from eternal darkness through these innocent sufferings. This sacred theme has been repeatedly raised in works, including musical art, by composers of various eras, style and worldviews, embodied in various musical,

28 Лосев А. История античной эстетики: Аристотель и поздняя классика. М.: Искусство, 1975. 
linguistic, style, timbre and instrumental means (for example, G. Schutz and J. Haydn). S. Gubaidullina's appeal in 1982 to such a complex theological concept reflects the trends of music of the second half of the XX century in the direction of "new spirituality".

The work of S. Gubaidullina, performed with avaricious intonational and musical means, reaches an unheard depth of spiritual experience, conceptuality. The laconicism of spiritual revelations is known; a clear system of their symbols, not always understood by our contemporaries; the parable of the language of Christ. So, during his cross suffering, Jesus said only seven phrases that formed the basis of the composition by S. Gubaidullina.

Two instrumental and textural finds-symbols representing the specifics of these particular instruments - their characteristic materiality, penetrate the entire musical fabric and broadcast the main idea of the work. This is a spatially tangible and succinctly inscribed short textured formula, a sacredly significant symbol of the Cross. The cello has the intersection of two adjacent (per second) and oppositely glissando sounds. The bayan has a non-tempered glissando where a vertical (a metal tongue detonating with the help of fur and carcasses detonating) and a horizontal (superimposed on the original voice pitch) are superimposed. This symbol of the Cross is played by parts and bayan, and solo cello, each separately. Moreover, this is a rather difficult to execute instrumentally thematic moment and it embodies the specifics of texture and sound extraction of instruments. In addition, the bayan embodies the symbolism of the organ church culture, and the cello earthly suffering, expressed by its «human» voice.

Another significant textured sign is a piece with accelerationdeceleration and, accordingly, crescendo-diminuendo with a bow (cello) and fur (bayan), embodying wave-like processes of tension and the symbol of the Cross: the vertical of expanded space and the horizontal of high-altitude intonation and spatial "folding" to the original sound supply status. Cross-shaped symbolism is also formed during the combination the symmetrical application of the timbres of the bayan and cello in a détaché with fur or bow.

The author's choice of instruments - the bayan and cello - from the point of view of spatial (musical and real) perception of sound production in the arrangement of instruments makes up a mystical conditionality with cross-shaped symbolism. The vertical intonationaltitude indicator of the keyboard keys and strings on the neck "intersects" with a specific means of sound extraction: horizontal movement of the bayan fur and cello bow. 
The first part is a word - "Father! Forgive them, they don't know what they are doing" - minimalistically built on tone $\boldsymbol{a}$ (symbol of light) and consists of the presentation of all three described cross-shaped symbols in the bayan and cello. The dramatic intersection of the two instruments unfolds into a powerful symmetrical moderation-crescendo and foldingdiminuendo. After a general pause - enlightened prayer «singing» of both instruments on $\mathrm{pp}$ - as the forgiveness of a sinless God.

The intonation center of the second part ("Wife! This is your son ... this is your mother!") - altitude $\boldsymbol{d}$. The cross-shaped symbols of the Cross, already familiar to us, alternate with "humanized" legato-voiced structures: the intonations of "crying" indicate the vocal nature of these melodic statements. Clusters of the bayan - the uneven gait of the Way of the Cross or the beats of the weak heart of the Crucified - are as empathy of the Father.

The third part ("Truly I tell you, now you will be with me in paradise") increases the tension of the Event. In the musical fabric, a cluster layer is activated; this naturally makes up mainly a bayan party. Octave fanfare is a harbinger of what will happen.

The fourth part ("My God, my God! What did you leave me for?") is large-scale in size, texture and dramatic tension. This is the moment of the highest suffering and human weakness of the God-man - an instant artistically "enlarged" into a large-scale composition. The melodic structures in the right and left keyboards of the bayan do not metrically coincide with each other, with the cello and the orchestra, demonstrating emotional imbalance.

The fifth part is "Drink". Against the background of small pizzicato cello utterances around the center $f$, the bayan player continuously performs the non-tempered glissando, which is usually used not so often in a row: a complicated performing technique as the lasting suffering of a thirsty.

In the Sixth part ("It happened"), Gubaidullina uses a graphical record of various sonor-aleatory "explosions": clusters of various intensity, sound-quality filling, duration, range, dynamics, as well as naturalistic "sigh-sobbing" of the bayan air intake (device buttons for silent compress-drop of fur). Perhaps these recordings of sonor effects were made for the first time in the bayan literature. All this makes up, on the background of the orchestral second "glide", the embodiment of the unearthly nature of musical expression: the Mysterious happened.

The final Seventh part - "Father! In Your hands I give my spirit" represents a sound reflection of the Mystery that is immense for the human mind, which is set forth by "otherworldly" ("non-own") timbre- 
invisible instruments. The cello has harp flagships against the background of extended durations behind the stand. The bayan has heterophonic polyphony in both keyboards around the tone $\boldsymbol{a}$ of the second octave: long trills against the background of a sustained note in the left keyboard, which do not coincide in meter with the two-voice of the right keyboard - syncopations and small chromatic "whirling» (a kind of complex intersection).

A cross-shaped texture is formed twice in the orchestra. However, everything disappears...

Thus, the musical idea of the work is composed of symbols of various levels: textured, high-altitude, metro-rhythmic means; personification of solo instruments taking into account their individual instrumental specifics. Dramatic dynamics is achieved by textural and timbre tension and visually perceived instrumental effects. These instruments take on not only thematic, but also compositionally-forming, structural functions, as well as the expressed functions of the symbol and image. It is also important that the artistically-philosophical aspect of the performing process in the presentation of such symbolism, the ability of the performer to create a special spiritual and creative "pre-tuning" in the performance. It is not without reason that the work is dedicated to experienced, "verified" like-minded composers - cellist V. Toncha and bayan player F. Lips.

The sound image and symbolism of the bayan and cello are presented as clearly as possible in sound and visual aspects. This is especially true for the image of the Cross, which is literally «drawn» on the instruments and in the performing movements of musicians. It creates the impression of a church space where the actions and prayer of the priest and parishioners are combined into a single whole with architectural and pictorial means and sounding music. Their «difficult amount» greatly enhances the impact. The personification of the bayan and cello gives the instruments a figurative characteristic, recognizable by individual and, at the same time, generalized features.

\section{CONCLUSIONS}

Thus, the symbolism of musical instrumentalism, reflecting the key positions of the philosophical image of the world and the materiality of the instrument itself, embodies the important semantic postulates of a person's spiritual and mental life in the dynamics of their development. It is a symbol of the universe harmony.

Musical and instrumental symbols (and semantics), forming over the course of a thousand-year history of culture and appearing as a sign of 
music itself (which is most actively used in related forms of art, primarily literature, poetry, painting), contributed to the birth of signs-images of individual instruments both in musical art, and in related forms of creativity. Translation of functional and situational, genre, style, and semantic parameters of such signs-images is inevitable even when playing on modernized instruments and in interpreting the latest style and language means of music. Preservation of symbolic memory accumulated over centuries contributes to the integrity of a specific instrumental culture, while being open to both individual style (composer and performing), as well as epoch-making innovations, general heuristic settings.

In the context of the stated problems, the concept of "sound image of an instrument" is gaining importance. For its evolution, several interdependent factors become significant: performing traditions, composer language (text), organological parameters of the instrument (all three contribute to the identification of new expressive techniques of the play), as well as the cultural and historical, semantic and symbolic fields that developed during the participation of this instrument in the spiritual, ritual, leisure and domestic, literary and poetic, pictorial and philosophical contexts.

In general, given the presence of the figurative beginning, as the figurative reincarnation of objective reality, in all forms of musical creativity, the musical instrument itself, with the accumulation of the qualities of organological and performing technologies, the composer's repertoire with the corresponding ideological and figurative, genre and style baggage, becomes a sign-image that is characterized by the binary nature of instrumental material and ideational (spiritual and philosophical, cultural and historical, social) parameters. Their combination, interconnections and mutual influences give grounds for creating a kind of "cultural personality" - an instrument of the era, nation, style, genre, individual quality with specific and universal characteristics.

In the semantic field "music" the image of a musical instrument (next to the images of a song, actually music, etc.) acts as one of the main semantic centers. In this process, one can state certain evolutionary positions in the direction of enhancing the personification and individualization of instruments, replacing wind instruments with strings, the formation of complex keyboards, crystallizing achievements of chamber ensemble and orchestral capabilities, the development of one's own language and communication methods. These vectors achieve their goal in the work of romantics, where the instrument becomes not just a 
mirror, but a double of the hero, his second «I $»$, sensitively reacting to all mental expressions.

The XX and XXI centuries continue the development of these processes of constructing image instruments, demonstrating the strengthening of instrumental materiality, which is proved by the example of partita by S. Gubaidullina for the bayan, cello and the chamber orchestra "Seven Words".

\section{SUMMARY}

The mechanisms and nature of musical significance, symbolism, sign remain promising objects of scientific research nowadays. The point here is not only the need for a certain sign system in a "pure" musical and instrumental "message", communication, where there is no verbal text that largely determines or contributes to the formation of a holistic meaning, as well as purely musical intonations in terms of instrumental accompaniment to singing. In purely instrumental creativity, the mechanisms of associative-sound memory are activated, preserving certain semiotic signs of the instrument itself in its materialized organological (timbre, type of instrument, methods and techniques of the play), as well as situational and substantive (ritual, leisure, work processes, etc.) and genre and style expressions.

Musical and instrumental symbols (and semantics), forming over the course of a thousand-year history of culture and appearing as a sign of music itself (which is most actively used in related forms of art, primarily literature, poetry, painting), contributed to the birth of signs-images of individual instruments both in musical art, and in related forms of creativity.

In the semantic field "music" the image of a musical instrument (next to the images of a song, actually music, etc.) acts as one of the main semantic centers. In this process, one can state certain evolutionary positions in the direction of enhancing the personification and individualization of instruments. The XX and XXI centuries continue the development of these processes of constructing image instruments, demonstrating the strengthening of instrumental materiality, which is proved by the example of partita by S. Gubaidullina for the bayan, cello and the chamber orchestra "Seven Words".

\section{REFERENCES}

1. Башарова И. Образ флейты в сонатине Губайдуллиной. Вестник Башкирского Университета. Уфа, 2008. № 3. С. 595-598. 
2. Буданова Т. Музыка для баяна композиторов Сибири и Дальнего Востока: автореф. дисс... канд. искусств.: 17.00.02. Владивосток, 2009. $21 \mathrm{c.}$

3. Воронова О.Е. Сергей Есенин и русская духовная культура. Рязань: Узорочье, 2002. 520 с.

4. Гаккель Л. Фортепианная музыка XX века: Очерки. 2-е изд., доп. Л.: Сов. композитор, 1990. 288 с.

5. Гервер Л. Музыка и музыкальная мифология в творчестве русских поэтов (первые десятилетия XX века). М.: Индрик, 2001. $248 \mathrm{c}$.

6. Давыдова, А. В. Музыкальные образы в русской лирике начала XX века: автореф. дисс. ... канд. филол. наук: 10.01.01. Архангельск, 2006. 24 с.

7. Зайнетдинова Р.А. Становление проблемного поля концепции семиосферы Ю.М.Лотмана: историко-философский анализ: автореф. дисс. ... канд. филос. наук: 09.00.03. Екатеринбург, 2011. $24 \mathrm{c}$.

8. Иванова С. Эволюция звукового образа балалайки: автореф. дисс... канд. искусств.: 17.00.02. Магнитогорск, 2009. 26 с.

9. Карабегова Е. Символика музыкальных инструментов в немецкой литературе XIX - XX веков и «Контрабас» Патрика Зюскинда. URL: http://natapa.msk.ru/sborniki-pod-redaktsiey-nt-pahsaryan/simvolika-muzykalnyh-instrumentov-v-nemetskoyliterature-xix-xx-vekov-i-kontrabas-patrika-zyuskinda.html

10. Лазутина Т.В. Процесс символизации в музыке: дис. ... канд. филос наук: 09.00.01. Тюмень, 2003. 139 с.

11. Лосев А. История античной эстетики: Аристотель и поздняя классика. М.: Искусство, 1975. 776 с.

12. Малинковская А.В. Класс основного музыкального инструмента. Искусство фортепианного интонирования. М.: Владивосток, 2002. 381 с., нот.

13.Мастерс П. Богослужение: библейское и современное. URL: http://torrents.te.ua/to17032

14.Откровение. Глава 8. Новый завет. URL: https://bible.by/nrt/66/8/

15.Рябуха Н. Звуковий образ як феномен культури: досвід міждисциплінарного синтезу. Культура $i$ сучасність. К., 2014. Вип. 2. С. 112-120.

16. Семиотика: Антология / сост. Ю.С. Степанов. Изд. 2-е, испр. и доп. М.: Академический проспект; Екатеринбург: Деловая книга, $2001.702 \mathrm{c}$. 
17.Сухов А.В. Музыкальные образы как отражение апокалипсических мотивов в поэме с. А. Есенина «Сорокоуст». Известия высших учебных заведений. Поволжский регион. 2015. № 4 (36). C. 126-134.

18. Тимошенко А. Американский музыкальный экспериментализм первой половины XX века: представление о звуке, концепция инструмента, композиции (Г. Коуэлл, Дж. Кейдж, Л. Хэррисон): дисс. ... канд. искусств.: 17.00.02. СПб., 2004. 254 с.

19. Chernoivanenko A. Musical and instrumental foundations of modern composition techniques. National academy of managerial staff of culture and arts Herald. 2'2019. S. 444-448.

20.Copland A. Music and imagination. Cambridge: Harvard University Press, 1952. Second printing. 116 p.

\section{Information about the author:} Chernoivanenko A. D., Candidate of Art, Professor, Odessa National A. V. Nezhdanova Academy of Music 63, Novoselskogo str., Odessa, 65023, Ukraine 